Bodies moving and being moved: mapping affect in

Christian Nold's Bio Mapping

\author{
Dr Gavin MacDonald \\ Department of Media \\ Manchester School of Art \\ Manchester Metropolitan University \\ Chatham Building, Cavendish Street \\ All Saints, \\ Manchester, M15 6BR \\ g.macdonald@mmu.ac.uk \\ 01612471258
}




\section{Bodies Moving and Being Moved: Mapping Affect in}

\section{Christian Nold's Bio Mapping}

\section{Gavin MacDonald}

In A History of Spaces, John Pickles notes how some of the ideologicallyloaded representational norms of mapping are well known, such as the orientation of maps with north at the top and the continued use of the Mercator projection (2004). Others are less familiar, including what Pickles calls 'the focus of mapping convention on natural and built physical objects, rather than developing universal conventions dealing with symbol, affect or movement' (2004: 57). However, since May 2000, when the US Government ended its purposeful degradation of the consumer global positioning system (GPS) signal which it had enforced for reasons of national security, the mapping of movement has been an area of considerable and ongoing artistic activity, and features as a significant aspect of a genre of new media art practice known as locative media (Hemment 2006; Tuters and Varnelis 2006; O'Rourke 2013; Pinder 2013; Zeffiro 2012). One artist working with GPS and traces of movement has also addressed cartography's blind spot of affect, incorporating an entirely different type of trace into his mapping practice. Christian Nold's longrunning Bio Mapping project (2004-ongoing) is a series of self-contained participatory mapping projects, all of which involve the combination of location with physiological data from a sensor that measures galvanic skin response (GSR), that is, changes in the conductivity of the skin of the subject's fingers caused by the level of their sweat (2009a; 2011 ['Bio Mapping']). Nold has likened the resulting visualisations to a 'cardiogram put across the landscape' (Nold and Bentkowska-Kafel 2006). GSR has been used as index of arousal by scientists researching emotions and affective responses since the late nineteenth century (Joyce and Baker 2008). Separately from this - although sometimes drawing on empirical science for legitimation - there has also been a resurgence of academic interest in affect and emotion (and the distinction between them) within the humanities, evident from the mid-1990s onwards. In what follows, I will be drawing on the Deleuzian/Spinozan concept of affect employed in a strand of this writing, and particularly on an influential essay by the philosopher Brian Massumi which works, on the level of rhetoric at least, to link affective science to the cultural theory which shares its name (Massumi 2002). ${ }^{1}$

Nold's project blends traces of the body's internal states with the traces produced by locomotive movement. This article considers this blending of traces, and the implications of a conflating a Deleuzian/Spinozan concept of affect with a framework derived from affective science. I will argue that one consequence is an erasure of the distinction between the two bodily phenomena being traced, and I will 
consider the role of a strategic scientism, evident in both Nold's and Massumi's handling of affect.

\section{Tools for Crowds}

Nold has a background in political activism, and while his work with participatory mapping has largely been funded and conducted (in the UK, at least) in the broad context of New Labour's instrumentalisation of socially engaged art, ${ }^{2}$ he has worked to retain a critical and reflexive attitude to both the basic conceptual elements of that practice (concepts like 'participation' and 'community') ${ }^{3}$ and to the technology that is at the heart of his work. His practice is concerned with both the production of practical tools for the representation of social collectives, and also with stimulating critical dialogues about technology more broadly, including the imaginaries that are stimulated by, projected onto and bound up with the development of new technologies.

In his work prior to Bio Mapping, the collectives with which Nold dealt were political crowds. One work from this period prefigures an interest in visualising the traces of moving bodies: Crowd Compiler (2004-5) is software art, an application that sequentially processes images taken at regular intervals by a fixed camera, compositing all the visual changes between the images and making them simultaneously visible. Essentially a chronophotography for crowds, Crowd Compiler sought to create images that captured their changing, temporal and mobile aspects. As Nold put it, 'most representations of the crowd aim to rationalise and quantify the crowd rather than show its dynamics of both density and fluidity. The Crowd Compiler software tries to present the "crowd in time" rather than a static snapshot' (2011 ['Crowd Compiler']). A composite digital photograph produced using the Crowd Compiler application was exhibited along with a computer running the software at Bruno Latour and Peter Weibel's 2005 Making Things Public exhibition at the Zentrum für Kunst und Medientechnologie Karlsruhe.

An essay written by Nold for the catalogue places his application in the context of long-standing problems with the representation of crowds in political discourse and their legitimacy in the eyes of legal authorities as expressions of public political will (2005). Nold starts his account with the 'earliest known photographs of a political crowd', images which he states 'indicate a turning point in the relationship between politics, representation and authority': two daguerreotypes taken of the Chartist meeting on Kennington Common in London, on 10 April 1848 (2005: 846). The image exhibited in Making Things Public was also taken at this location. Nold relates the problems the Chartists met in trying to get their petition recognised by Parliament and describes controversies over the number of signatures, with the counts conducted by the organisers and government differing widely. ${ }^{4} \mathrm{He}$ draws parallels with the protest held on 15 February 2003 against the then-impending invasion of Iraq, a demonstration which is generally acknowledged as the largest such event in British history. Figures varied then also, with the Metropolitan Police claiming 750,000 protestors and the Stop the War Coalition claiming up to two million (2005: 852). Nold describes the different statistical and observational techniques used by 
different parties in London and elsewhere on that day: for official and some media estimates, these involved the use of aerial photographic data. However, Nold's Crowd Compiler is not intended as a more accurate way of counting heads: in his essay's conclusion he criticises the reductiveness of 'the crowd-number discourse' (2005: 853), something of which all parties are guilty.

Nold's essay closes with a call for a more nuanced version of collective representation, and although Crowd Compiler is the model he is proposing, his last words on the subject describe a synoptic visuality far more like a bottom-up cartography than the digital chronophotography produced by his application:

Today, this view of power has been placed in the hands of those with the necessary imaging technology. Fortunately, there is a whole movement of bottom-up media technologists who are developing new communication and representation technologies. Instead of rushing home from a demonstration to have our own subjective experience validated by the mainstream media, these new strains of technology hint at ways to attain our own consensual God's-eye view. (Nold, 2005: 853)

Although Crowd Compiler cannot be considered a locative media artwork, in their survey of the genre Marc Tuters and Kazys Varnelis use it to illustrate the rationale of that strand of locative media practice concerned with tracing movement (2006). In turning to locative media, Nold would develop a tool that combines the embodied, subjective experience of the individual at street level with the God's-eye view of GPS.

\section{Performative Mapping and Paper Maps}

Nold's Bio Mapping device patches together two technological objects. GSR sensors register the skin resistance of the participants, passing a small current through the skin of their hands via finger cuffs. The level of sweat increases the rate of conductance, and this provides a measurable parameter relating to the internal state of the participant. Nold is concerned with short-term peaks and dips in the GSR reading; he states that "the assumption is that these changes are an indication of "emotional" intensity' (2009c: 3). Indeed, as mentioned above, GSR has been used in scientific studies into emotion for over a hundred years (Joyce and Baker 2008).

Most of the large mapping projects Nold has undertaken using this device have been titled Emotion Maps, ${ }^{5}$ and he has published an anthology of critical and technical writing on the project and its themes entitled Emotional Cartography (2009b). However, despite these project titles, Nold is generally circumspect about the claims he makes for his device and repeatedly stresses that the GSR reading is meaningless without the active interpretation of the participants. Nold intends his technology to stimulate dialogue and reflection in two ways: firstly, about the places mapped and the project participants' affective engagement with them; and secondly, about the reality and fantasy of a technology able to plot internal states objectively in this way (2009c). 
Nold's initial intention for the technology was less concerned with mapping than with critiquing 'the currently dominant concept of pervasive technology', and its extension into the space of the body (2009c). He has stated that the cartographic side of his project only emerged as a consequence of his experience developing and working with the biometric device:

It wasn't so much that I set out to make these participatory maps, the whole idea of doing these collective mappings only grew out of a process. I think my main frustration with a lot of art projects is that they have a very clear end point, and they don't iterate, whereas I think in this project I developed a small thing, and through that I discovered people who were making interesting meaning out of this, and out of that I kind of iterated the way it was used and it became something different. Because I did it over a period of years it grew into these emotion maps and various other contexts. (Conversation with the author, 28 July 2010)

With Bio Mapping, Nold is more concerned with an iterative process than with any particular representational outputs. Cartographic theorists have identified a recent shift toward performative understandings of mapping rooted in embodied experience and practice: Chris Perkins locates these new understandings in the context of 'a shift in the humanities and social sciences from considering texts as the bearers of culture, toward performative ways of knowing the world, in which the dynamic aspects of culture matter ... the philosophical shift away from representation, toward action' (2009: 126). Perkins identifies artists' work with cartography as one area in which a performative tradition of mapping is being enacted, and singles out art practices involving locative media as 'particularly performative', using Nold's work as an example of this (2009: 132).

[FIG 1 TO GO AROUND HERE]

Nonetheless, Nold's practice is still characterised by the attention paid to the final form of the mapped output. Even if the emphasis of his large-scale participatory projects is on the process and the dialogues engendered, they still result in more-orless traditional cartographic representations: paper folding maps which emulate the production values and formats of official cartography. For example, the Greenwich Emotion Map (Figure 1) is an A0 paper map, the same dimensions as the Ordnance Survey's Explorer series of walking maps and designed to mimic their distinctive orange covers. It was, in fact, printed by the Ordnance Survey for the project (although its scale was rather larger, at 1:3,530 rather than the Explorer's 1:25,000) (Nold 2006).

Yet although this printed map was produced and distributed at the end of the project, it is only one possible form that the data gathered by the project can take; Nold has also distributed the data from his Bio Mapping projects via his own website or the websites specific to each project, in file formats that that can be readily visualised and manipulated in geospatial applications such as Google Earth. ${ }^{6}$ Perkins notes that another way in which performative traditions of cartography are being 
enacted is in everyday mapping performances that exploit the geospatial web: from enthusiasts' collaborative mappings like the OpenStreetMap project, to the simple use of interactive mapping services to produce customised maps for directions or of local services (2009). ${ }^{7}$ Furthermore, although Nold's paper map comes with the trappings of an authoritative representation of space, one with what critical cartographer Denis Wood calls 'the hubris to present the world ... as it really is' (2010: 26), its plotted contents are clearly fleeting and subjective: the routes walked by a limited group of participants during the period of the project (October 2005 to March 2006) and the events of arousal registered by the GSR sensors worn by those individuals as they walked. In terms of the conventional expectations of objectivity and authority in cartographic representation, the most that can be said of this data is that in its distribution and clustering it might show something of the intersubjective experience of intensity in Greenwich for a limited group of people during a defined period.

\section{Mapping Affect}

For over a hundred years, researchers working in affective science have predominately worked with a dimensional approach to emotion; that is, they argue that the distinct commonsense emotions (anger, delight, happiness, sadness and so on) are grounded in more basic properties, usually two. Arousal or intensity is one of these 'psychological primitives' and the other is valence, the hedonic (that is, positive or negative) aspect of an emotional response. Together these properties are used as the axes of graphs on which all emotional responses can be plotted and described in necessary, if not sufficient, terms (Feldman Barrett and Russell 2009; Brosch and Moors 2009).

While GSR is often taken as an index of arousal or intensity, valence is much harder to capture in a way that satisfies the scientific requirement for objectivity. Nold's Bio Mapping project also deals with the hedonic axis of emotion but, far from striving for an objective measure, he embraces the attitude that 'you can talk about valence in a much more human way, where it's about the interpretation' (conversation with the author, 28 July 2010). In each project, visualisations of geographic and biometric traces are used as the basis of a group workshop in which participants narrate their walks and qualify their emotional responses. These initial visualisations are distinct from the paper maps produced at the end of each project which combine the disclosures collected in the workshops with the traces produced by the Bio Mapping device. Nold has stated that 'the [initial] visualisation of the data only allows that discussion to take place. So the end product is the combination of this concious [sic] reflection on this "pseudo" scientific data' (Nold and Bentkowska-Kafel 2006). What seems clear from this is that the project's technological trappings are less to do with science and more to do with a certain strategic scientism, and that the value of the GSR data for Nold is less in what it represents than what it permits.

However, for all of Nold's circumspectness regarding the data and the technology that underpins his work, and for all of the emphasis that he places on the processes and dialogues the technology permits, the GSR data is still an empirical index of bodily intensities. There has been a noticeable turn to affect and emotion in 
the humanities in recent years, dateable back to the mid-1990s. ${ }^{8}$ In an influential essay, Brian Massumi discusses the use of GSR meters in experimental research into emotional responses to television programmes (2002: 23-45). He uses the findings of one particular experiment as the basis for arguing that intensity of the sort that GSR indexes, manifested 'in the skin - at the surface of the body, at its interface with things' (2002: 25), is a communicative circuit that exists in parallel with what he calls 'the determinate qualities of the image' (2002: 25). GSR indexes its content to conventional, intersubjectively understood meanings: language, more or less (this is not to say that the two circuits are isolated - Massumi argues that they are capable of resonating or interfering with each other). Massumi provisionally equates GSR data to affect; ${ }^{9}$ however, rather than affective science Massumi's understanding of the concept draws far more on Gilles Deleuze's reading of the seventeenth-century philosopher Benedict de Spinoza. This is a key element in Massumi's attempt to rewrite the body into a cultural studies that he argues has excluded it in favour of structure and language. ${ }^{10}$

Deleuze revives the distinction between two Latin terms that translators of Spinoza had generally conflated as 'emotion': affectus and affectio. Affect (affectus) is 'a prepersonal intensity corresponding to the passage from one experiential state of the body to another and implying an augmentation or diminution in that body's capacity to act' (Massumi 2004: xvii; see also Seigworth 2005). It is the variation of intensity of a body, corresponding to an openness to the influence of other bodies and capacity to effect change on them, strung out along the line of its life. An affection (affectio) is an event of connection between bodies, 'each such state considered as an encounter between the affected body and a second, affecting body' (Massumi 2004: xvii). Affect is virtual rather than actual: it belongs to 'the pressing crowd of incipiencies and tendencies ... [the] realm of potential' (Massumi 2002: 30). Affect is relational, it involves thinking of the body in its virtual aspect as being open to its context and the influence of other bodies.

Bodies here should not be thought of as exclusively referring to human bodies. In Spinoza's monism, all of reality is one substance and all entities within it, ideal and actual, are considered modes of that substance. As they are all one substance, bodies are differentiated from each other first by movement, in terms of relations of motion and rest. All of the entities we encounter are compounds, relatively stable arrangements of simpler bodies, moving in concert. Bodies are therefore conceived of as 'any whole composed of parts, where these parts stand in some definite relation to one another, and has a capacity for being affected by other bodies' (Baugh 2010: 35). Spinoza's ontology levels the distinction between entities: the category of bodies includes human beings and other living things, social bodies at different scales (bodies nest within other bodies: there are bodies 'all the way down'), inanimate matter, texts, ideas.

Nold is clear that the GSR readings in his Bio Mapping projects are not documenting emotion, 'but actually a variety of different sensations in relation to the external environment such as awareness, sensory perception and surprise' (2009c: 5). 
Likewise Massumi distinguishes between emotion and the intensities that he equates with affect:

An emotion is a subjective content, the sociolinguistic fixing of the quality of an experience which is from that point onward defined as personal. Emotion is qualified intensity, the conventional, consensual point of insertion of intensity into semantically and semiotically formed progressions ... into function and meaning. It is intensity owned and recognised. (2002: 27-8)

Following Massumi in provisionally equating the intensities indexed by GSR with affect, and in splitting affect from emotion, it can be seen that far from simplistically mapping emotion, the physiological side of Nold's device in fact provides the grounds for such a mapping which occurs in the group workshops. Each geo-located peak of intensity is an affection, in the terminology Massumi and Deleuze derive from Spinoza. Seen in this way, the narratives and discussions opened up by the GSR data relate to the bodies and lives of the participants in their virtual aspects, in all their openness and connections, and produce a social understanding of space.

In his statement on the Greenwich Emotion Map, Nold notes that it works on three different levels:

At a basic level, the map shows a sensory space of embodied experience ... At another level, we seem to see the effects of the built environment represented by traffic crossings and comments about particular local features. But perhaps most striking is the prominence of a third level: that of people's social interaction. This social space - which might be seen as ephemeral and temporary, including as it does surprise meetings with friends, neighbours and strangers - appears to be more important than the other levels. (Nold 2006)

If we accept Massumi's equation of the intensities registered by GSR sensors with a Deleuzian/Spinozan concept of affect, then the prominence of the social in the outputs from Nold's Bio Mapping is inevitable. Describing the way that affect has been understood in human geography, Steve Pile notes that it 'is not simply personal or inter-personal ... it is transpersonal, drawing in many bodies. Affect, then, is both within and between bodies' (2009: 8). The phenomenon mapped by Nold's device and used as the basis of a mapping of emotion is, Massumi argues, part of a 'field of emergence' (the virtual) that is 'open-endedly social' (2002: 9).

\section{Bio Mapping and the Social}

Nold states that media interest in his device in the mid-2000s led to him fielding enquiries about his device from parties ranging from academic researchers to individuals seeking new therapeutic devices and commercial concerns: 
Estate agents in California wanting an insight into the geographical distribution of desire; car companies wanting to look at drivers' stress, doctors trying to re-design their medical offices, as well as advertising agencies wanting to emotionally re-brand whole cities ... I was shocked: my device, or more correctly, the idea or fantasy of my device had struck a particular 21st century zeitgeist. (Nold 2009c: 4)

Nold's discomfort with some of these approaches prompted him to seek to define his own vision of Bio Mapping as a socially engaged art practice: this involved shifting the emphasis of the project away from the device itself toward developing and documenting 'a reflexive and participatory methodology' (Nold 2009c: 4). The key to this development was a shift to a community-based practice. From the project's inception in 2004 to 2006, Bio Mapping was mainly exhibited in group shows in art gallery contexts, involving casual participants. These were generally drawn from audiences with a specific interest in contemporary or new media art rather than those with a particular stake in the place being mapped. ${ }^{11}$

In contrast, for the Greenwich Emotion Map project, Nold worked for six months (October 2005 to March 2006) with a total of 50 local residents, holding weekly group workshops. After Greenwich, Nold concentrated on longer projects in which he worked with communities. Distinguishing between these two phases of the project, Nold notes that there was a much richer engagement with the task in the latter group:

It started becoming about the local development and how people felt about it, it became about the history, it became about the individual personal stories, whereas when you did it in the centre of town it was often about incidents, you know, fell over, dog poo, raining, ice cream, had a burger, saw somebody attractive. (Conversation with the author, 28 July 2010)

Nold's methodology has two characteristics that bear mentioning. Firstly, the interpretation and narration of the traces happens after the walk itself: Nold considered and rejected the use of real time data early on in the project. ${ }^{12}$ This contrasts with many other locative media participatory mapping projects, such as Esther Polak's Amsterdam RealTime (2002) and Jen Hamilton and Jen Southern's Running Stitch series (2006-9), which used real time data. Secondly, while these other mapping projects all involved central, visual foci in the form of projected maps in gallery spaces, the Greenwich Emotion Map was more about creating a particular type of situation for its participants, described by Tom Corby as 'an open-ended discursive event whereby meanings emerge from the shared subjective responses of groups of users' (2008: 465). In Nold's Bio Mapping projects, participants describe and discuss their subjective bodily data as a group:

At the beginning I was doing them one-to-one, and actually it's not so interesting, it's much more interesting when you hear a group of people 
who are all experts in the local area, and one person who is with a group of people that they don't know suddenly is happy to talk about their quite personal experiences, including fairly intimate ideas of themselves and quite political ideas. So there's originally a collectivity in the way that we gather the data and bring it together. (Conversation with the author, 28 July 2010)

Nold thinks of the Bio Mapping tool as a 'performative technology' in two ways: firstly, it allows people to walk and experience their localities as performances, rendering the familiar strange through the knowledge that this prosthesis is making their intimate body states legible for a future audience. Secondly, in the workshops, the device and the quasi-scientific affect data that it has produced work to mediate social relationships between strangers whose only connection may be a mutual relationship with the area being mapped. Nold states that the device

shoulders the burden of having to hold the public's attention, while offering a safe distance from public exposure to the 'interpreter'. Used in this way, the tool allows people who have never met each other to tell elaborate descriptions of their own experiences, as well their [sic] opinions on the local neighbourhood, in a way that they would have never done otherwise. (Nold 2009c: 6)

'Community' is a term that often comes freighted with essentialising and conservative assumptions relating to place and identity, even when it is used in supposedly progressive art practices. Writing in the mid 2000s, Claire Bishop identified a 'social turn' in art, a 'recent surge of artistic interest in collectivity, collaboration, and direct engagement with specific social constituencies' which has gone under many names (2006: 178). Extending critiques of imposed, monumental and elitist public art first developed through site-specific practices during the 1970s, artists working within these participatory genres use 'social situations to produce dematerialised, anti-market, politically engaged projects that carry on the modernist call to blur art and life' (Bishop 2006: 179).

Christian Kravagna has described how different strands of participatory art, while sharing the background Bishop describes, vary considerably in the way they conceive of the communities that are their rationale and medium, noting that 'some understand the community as pre-existent and, therefore, tend to attribute a (fixed) identity to it ... [while] for others, community is a temporary phenomenon with a potential for development that emerges in the course of the project' (2010: 254). In a related discussion, Bishop has critiqued the concept of community operative in artworks from the relational aesthetics genre that emerged during the $1990 \mathrm{~s},{ }^{13}$ which, although not framed as public art, are similarly participatory and concerned with reaffirming social relations: 'an ideal of subjectivity as whole and of community as immanent togetherness' (2004: 67). Bishop argues instead for participatory art practices that expose antagonistic currents in society, these being the true basis of a pluralist democracy. 
Locative media is certainly not immune from essentialist ideas of community. Sean Cubitt, generalising from a description of Urban Tapestries (2002-4), a 'public authoring' locative media project which allowed participants to annotate their environment with notes and narratives (Proboscis 2002), states that:

There is undoubtedly a nostalgic tinge to this type of locative art, a belief that in some way a mythicised urban community might be brought into being on the basis of a tradition that is not only lost but invented, and that meaningful places might supplant the meaning-free spaces which have become our lot. (Cubitt 2010: 167)

The concept of community operational in Nold's Bio Mapping projects is antiessentialist, with a temporary and limited collective emerging through the framework of his methodology and the mediation of his 'performative technology'. It is also far from homogeneous, being open to the antagonist currents that Bishop describes. The supporting text for the Brentford Biopsy project (2008) explains that:

The texts on the map are those of multiple voices often disagreeing with each other or speaking from different points of view, but always trying to make sense of their environment ... its central aim is to hold up the complex network of local issues for all to see and reflect upon and not to attempt to untangle or resolve them. (Nold and Boraschi 2009: 85)

\section{[FIG 2 TO GO ABOUT HERE]}

\section{Nold's Cartography}

Nold has visualised the trace data from his Bio Mapping projects in different ways, employing various technologies. In his earliest projects, from 2004, he used scanned paper maps as a base map and visualised participants' routes simply, with coloured dots for each log of arousal and location. In later projects he has used Google Earth, plotting geographic and biometric data as one line, with the GSR data replacing the vertical (altitude) datum of GPS (Figure 2).

The aerial photography layer of Google Maps acts as a base map, tilted to an oblique bird's-eye view so that each route appears as a jagged, three dimensional graph of arousal. Equating affect to the bodily intensities indexed by GSR, these visualisations can be taken as referring specifically to affectus as 'a line of continuous variation in the passage of intensities' (Seigworth 2005: 166) and 'a gradient of bodily capacity [to affect and be affected]' (Seigworth and Gregg 2010: 2). The jaggedness of this line is the result of the GPS side of Nold's device logging location punctually, every four seconds. But this technical limitation notwithstanding, the combined geographic/physiological line is also a record of punctual events of encounter between bodies - affections (affectio), actualisations of the virtual, 'affect turned effect' (Seigworth 2005: 166). As Nold says of his participants:

While I would see just a fairly random spiky trail, they saw an intimate document of their journey, and recounted events which encompassed the 
full breadth of life: precarious traffic crossings, encounters with friends, meeting people they fancied, or the nervousness of walking past the house of an ex-partner. (Nold 2009c: 5)

These three-dimensional visualisations are generally used in the workshop phases of Nold's projects, but his later community-focussed Bio Mapping projects have, as I have discussed above, also involved the production of a final visualisation in the form of a paper map. The cartography for these maps has varied from project to project, both stylistically and in terms of content: for example the Stockport Emotion Map (Nold 2007) (Figure 3) ${ }^{14}$ includes sketches produced by the participants representing issues they associated with that town. However the maps also vary in the way they represent the two different datasets produced by the Bio Mapping device. While a line representing the participants' routes is present in both the Greenwich Emotion Map (Nold 2006) and the Stockport Emotion Map, it is absent from the San Francisco Emotion Map (2007) (Figures 4 and 5): here the street plan of the Mission District is picked out only in discontinuous arousal readings. Whereas both the Stockport and San Francisco maps represent the GSR readings as points, the Greenwich Emotion Map uses a rather different approach: a geographic information system was used 'to create a communal arousal surface which blended together 80 people's arousal data and annotations' (Nold 2009c: 7).

[FIGS 3-5 TO GO AROUND HERE]

This aggregation has implications, the most obvious being that the identity of the individual is subordinated to a collective identity where affect is concerned, if not in their movement. The Greenwich Emotion Map deals with the arousal data statistically: the GSR readings that stand in for the elevation datum of GPS are used to create a contour map of affect. Individuals are dissolved into isolines linking similar arousal readings. While the later maps do not follow this particular approach, they all anonymise the affective responses and thus dissolve the identities of individual participants in a collective. While the San Francisco Emotion Map seems to provide a thick aggregation of individual affections, in fact, each dot is a statistical average: the map's accompanying text states that 'the overall pattern of dots shows where the participants walked. The color of the dots represents the combined emotional data of all the participants' (Nold 2007). Even where spikes corresponding to individual responses are shown, as with the Stockport Emotion Map, the textual annotations which qualify those readings float free, without named authors. In all the maps, the GSR readings are unconnected to the lines denoting the routes taken by individual participants. Where the linear traces of movement have been removed altogether, leaving only a discontinuous distribution of intensities (as with the San Francisco Emotion Map), the sense of the dissolution of the individual subject is even more marked.

For Nold, the representation of a particular individual's movement and affective response is less important than bringing together the many traces, in his workshops, in order to form a collective representation of place. The way in which Nold represents bodily intensities in his maps purposefully attenuates any connection 
to specific participants. This subordination of individual subjectivity evident in his maps can be interpreted in terms of a Deleuzian/Spinozan concept of affect as 'prepersonal intensity' (Massumi 2004: xvii). These paper maps also suggest the possibility of locating affect outside the body, in virtual relations and circulations. Massumi states that 'the autonomy of affect is its participation in the virtual. Its autonomy is its openness. Affect is autonomous to the degree to which it escapes confinement in the particular body whose vitality, or potential for interaction, it is' (2002: 35). This openness to the virtual is also the possibility of change: these maps are therefore not representations of a static concept of what constitutes a place; rather, they are snapshots of place as an affective system, relational and always emerging.

\section{Nold's Bio Mapping and Deleuze's Cartography}

To recap, Nold's cartography plots two kinds of contents: the extensive movement of participants' bodies through space, rendered as a line by GPS; and events of physiological arousal, intensities that I have argued here can be interpreted in terms of affect rather than emotion, and a Deleuzian/Spinozan concept of affect in particular. But Deleuze has also discussed bodies and affective relations in terms that are directly relevant to Nold's practice. In his own writing and in his collaboration with Felix Guattari, Deleuze proposes a cartographic model for subjectivity or individuation, as Moira Gatens describes:

Deleuze's reading of Spinoza posits a 'social cartography', a means by which to map individuals on a plane of immanence [i.e. reality considered in its virtual aspect]. The coordinates comprise two major axes whose points of intersection offer an analysis in terms of intensive capacities and extensive relations. (Gatens 1996: 168)

In one use of Deleuze's cartographic model in his collaboration with Felix Guattari, these axes are referred to as longitude ('the sum total of material elements belonging to [a body] ... under given relations of movement and rest, speed and slowness') and latitude ('the sum total of the intensive affects [a body] ... is capable of at a given power or degree of potential') (Deleuze and Guattari 2004, 287). ${ }^{15}$ Gatens states that taken together, longitude and latitude 'provide an immanent appraisal of any given body rather than a taxonomic reading' (1996: 168). Rather than assessing a body in terms of what type of thing it is, we can assess it in terms of its relations: the internal ones, the quasi-stable arrangement of extensive elements which comprise a physical body; and its external ones, its variable capacity to affect and be affected (affectus, using the distinction introduced earlier). The two axes of this Deleuzian cartography are evident in the literally cartographic traces produced by Nold's device, as is best demonstrated in the oblique Google Earth visualisations of individual traces, where ongoing variations in affect are rendered as contours.

However, as I have already stressed, the bodies of Deleuzian/Spinozan affect theory are not restricted to the human. Deleuze and Guattari co-opt a word from medieval philosophy, 'haecceity' (literally, thisness), to describe a 'mode of 
individuation' distinct from object, subject or a definition in terms of a fundamental substance' (2004: 287). The examples they initially provide are all temporal unities: 'a season, a winter, a summer, an hour, a date have a perfect individuality lacking nothing, even though this individuality is different from that of a thing or a subject' (2004: 287-8). Haecceities are not simply events and locations expressed as coordinates in time and space, 'emplacements' as Deleuze and Guattari put it: they are affective bodies in their own right, 'concrete individuations that have a status of their own and direct the metamorphosis of things and subjects' (2004: 288). The affections distributed about Nold's maps are not just physiological effects in the bodies of his participants, they are also the latitudes of diverse other bodies: pitbulls, panhandlers and parks, as well as physical places associated with the memories of friends and former lovers (all these examples are taken from Figure 5).

In closing his 2006 survey of locative media arts, Drew Hemment puts forward Deleuze and Guattari's haecceities as a concept to which the genre could aspire (2006). He is referring mainly to the annotative strand of locative media; those works that involve placing and accessing site-specific digital media contents using a geographic coordinate system. ${ }^{16}$ Too often, he argues, works of this sort involve emplacements in Deleuze and Guattari's negative sense: discrete contents located in a space reduced to the strictly cartographic dimensions of longitude and latitude. If locative art is 'to exceed the sterile precision of its own axiomatic system' (Hemment 2006: 354), its practitioners need to conceive of their interventions as haecceities:

Locative arts can then come to be seen not as distanced from the world but as offering a potential for transformation and engagement, opening up other places, their contents circulating through location-aware networks, producing a field of relations and affects. (Hemment 2006: 354)

However, in likening the sited digital contents of annotative locative art to haecceities in this way, Hemment neglects the bigger ontological implications of the concept: if the plane of immanence, the world, is composed of such individuations, then the human bodies walking through and experiencing these affections are themselves haecceities. As Deleuze and Guattari state:

We must avoid an oversimplified conciliation, as though there were on the one hand formed subjects, of the thing or person type, and on the other hand spatiotemporal coordinates of the haecceity type. For you will yield nothing to haecceities unless you realize that that is what you are, and that you are nothing but that. (Deleuze and Guattari 2004: 289)

Seen in terms of Deleuze's concept of affect and his cartographic model for individuation, Nold's maps depict just this: haecceities yielding to haecceities. The two distinct kinds of trace captured by Nold's device, geographic and physiological, in fact index fundamentally similar phenomena, graphed along their longitudinal and latitudinal axes respectively. Elsewhere, in another use of his cartographic model, 
Deleuze makes it clear: 'Each of the two types of maps, those of trajectories and those of affects, refers to the other' (1998: 65). All of the marks on Nold's maps testify to bodies moving and being moved, whether they are those of the Bio Mapping participants or those (human or non-human) bodies that affect them.

From Nold's use of GSR readings, we have come to a Deleuzian/Spinozan interpretation of affect. However, in closing I am going to address my own use of affect theory in this discussion of Nold's work. Like Nold, I have tried to be circumspect, not least about Massumi's equation of the intensities registered by GSR with affect in the Deleuzian/Spinozan sense - at least I have tried to make it clear that it is Massumi's equation and that I am working with it provisionally.

Massumi begins and validates his essay with an appeal to empirical cognitive science into emotional responses and, as I have described, GSR is indeed used by scientists in this way, and has been for over a century. But I have some concern about this easy bridging of disciplinary domains. There is no agreed definition of affect in the affective sciences, just as there are different strands of social and cultural affect theory (Charland 2009; Thrift 2004). Although Massumi's separation of signals into affective and semantic/semiotic levels draws some support from the long-used dimensional approach to emotion (its separation into intensity/arousal and valence), these bipartite models are formally similar rather than identical.

My position is that there is no need to equate the dimensional model of affective science to the parallel circuits of linguistic meaning and physiological intensities: one can take the point that emotion is a qualified intensity without this appeal to science, just as one can accept that language is not the only way we are moved to action. Massumi's use of GSR in his essay opens up a space to talk about the body's openness to context and change by ranging across affect's disciplinary registers. There is a parallel here with Nold's use of GSR, which opens up a social space for hitherto unconnected individuals to collectively map their shared milieus. These are both strategic scientisms.

\section{Reference List}

Baugh, Bruce (2010), 'Body', in A. Parr (ed.), The Deleuze Dictionary, Revised Edition, Edinburgh: Edinburgh University Press, pp. 35-6.

Bishop, Claire. (2004), 'Antagonism and Relational Aesthetics', October, 110, pp. $51-79$.

Bishop, Claire (2006), 'The Social Turn: Collaboration and Its Discontents', Artforum, February 2006, 178-83.

Bourriaud, Nicholas (2002), Relational Aesthetics, Dijon: Les Presses du Réel.

Brosch, Tobias and Agnes Moors (2009), 'Valence', in D. Sander and K. R. Scherer (eds), The Oxford Companion to Emotion and the Affective Sciences, Oxford: Oxford University Press, pp. 401-2. 
Charland, Louis C. (2009), 'Affect (Philosophical Perspectives)', in D. Sander and K. R. Scherer (eds), The Oxford Companion to Emotion and the Affective Sciences, Oxford: Oxford University Press, pp. 9-10.

Clough, Patricia Ticineto and Jean O. M. Halley (eds) (2007), The Affective Turn: Theorizing the Social, Durham, NC: Duke University Press.

Corby, Tom (2008), 'Landscapes of Feeling, Arenas of Action: Information Visualization as Art Practice', Leonardo, 41:5, pp. 460-7.

Cubitt, Sean (2010), 'Internet Aesthetics', in J. Hunsinger, L. Klastrup, and M. Allen (eds), International Handbook of Internet Research, Berlin: Springer Verlag, pp. 159-70.

Deleuze, Gilles [1970] (1988), Spinoza: Practical Philosophy, San Francisco: City Lights Books.

Deleuze, Gilles (1998), Essays Critical and Clinical, London: Verso.

Deleuze, Gilles and Felix Guattari [1980] (2004), A Thousand Plateaus: Capitalism and Schizophrenia, London and New York: Continuum.

Feldman Barrett, Lisa and James A. Russell (2009), 'Circumplex Models', in D. Sander and K. R. Scherer (eds), The Oxford Companion to Emotion and the Affective Sciences, Oxford: Oxford University Press, pp. 85-8.

Gatens, Moira (1996), 'Through a Spinozist Lens: Ethology, Difference, Power, in P. Patton (ed.), Deleuze: A Critical Reader, Oxford: Blackwell, pp. 162-87.

Gregg, Melissa and Gregory J. Seigworth (eds) (2010), The Affect Theory Reader, Durham, NC: Duke University Press.

Harrison, Ellie (ed.) (2005), Day-to-Day Data: An Exhibition of Artists Who Collect, List, Database and Absurdly Analyse the Data of Everyday Life, Exhibition Catalogue, Nottingham: Nottingham City Museums \& Galleries.

Hemment, Drew (2006), 'Locative Arts', Leonardo, 39:4, pp. 348-55.

Hemmings, Clare (2005), 'Invoking Affect', Cultural Studies, 19:5, pp. 548-67.

Hope, Sophie, \& Stamenkovic, Marko. (2008). Exploring Critical and Political Art in the United Kingdom and Serbia. In M. Jordan \& M. Miles (eds), Art and Theory After Socialism, Bristol: Intellect, pp. 77-87.

Joyce, Nick and David Baker (2008), 'The History Corner: The Galvanometer', APS Observer, 21:4,

http://www.psychologicalscience.org/index.php/publications/observer/2008/ap ril-08/the-history-corner-the-galvanometer.html [accessed 4 November 2013].

Kravagna, Christian (2010), 'Working on the Community: Models of Participatory Practice', in A. Dezeuze (ed.), The 'Do-It-Yourself' Artwork, Manchester: Manchester University Press, pp. 240-55.

Massumi, Brian (2002), Parables for the Virtual: Movement, Affect, Sensation. Durham, NC and London: Duke University Press.

Massumi, Brian (2004), 'Notes on the Translation and Acknowledgements', in Gilles Deleuze and Felix Guattari, $A$ Thousand Plateaus: Capitalism and Schizophrenia, London and New York: Continuum, pp. xvii-xx.

Nold, Christian. (2005), 'Legible Mob', In B. Latour \& P. Weibel (Eds.), Making Things Public: Atmospheres of Democracy, Karlsruhe, Germany and 
Cambridge, MA: ZKM Center for Art and Media with the MIT Press, pp. 846853.

Nold, Christian (2006), Greenwich Emotion Map: Visualising Social Space, London: Independent Photography.

Nold, Christian (2007), San Francisco Emotion Map. San Francisco: Southern Exposure.

Nold, Christian (2008), Greenwich Emotion Map, 4 November 2013, http://emotionmap.net/.

Nold, Christian (2009a), Bio Mapping / Emotion Mapping, 4 November 2013, http://biomapping.net/.

Nold, Christian (2009b), Emotional Cartography: Technologies of the Self, London: Christian Nold.

Nold, Christian (2009c), 'Introduction: Emotional Cartography: Technologies of the Self', in C. Nold (ed.), Emotional Cartography: Technologies of the Self, London: Christian Nold, pp. 3-15.

Nold, Christian (2011a), Christian Nold, 4 November 2013, http://www.softhook.com/.

Nold, Christian and Anna Bentkowska-Kafel (2006), 'Christian Nold Interviewed by Anna Bentkowska-Kafel', 3DVisA Bulletin, 1, http://3dvisa.cch.kcl.ac.uk/biomapping.html [accessed 9 September 2013].

Nold, Christian and Daniela Boraschi (2007), Stockport Emotion Map, Stockport: Softhook.

Nold, Christian and Daniela Boraschi (2009), 'Brentford Biopsy', in C. Nold (ed.), Emotional Cartography: Technologies of the Self, London: Christian Nold, pp. 83-7.

O’Rourke, Karen (2013), Walking and Mapping: Artists as Cartographers, Cambridge, MA: MIT Press.

Perkins, Chris (2009), 'Performative and Embodied Mapping', in R. Kitchin and N. Thrift (eds), International Encyclopedia of Human Geography, Vol. 8, Oxford: Elsevier, pp. 126-32.

Pickles, John (2004), A History of Spaces: Cartographic Reason, Mapping and the Geo-coded World, Abingdon: Routledge.

Pile, Steve (2009), 'Emotions and Affect in Recent Human Geography', Transactions of the Institute of British Geographers, 35:1, pp. 4-20.

Pinder, David (2013), 'Dis-locative Arts: Mobile Media and the Politics of Global Positioning', Continuum: Journal of Media and Cultural Studies, 27:4, pp. $523-41$.

Proboscis (2002), Urban Tapestries / Social Tapestries: Public Authoring and Civil Society in the Wireless City, 4 November 2013, http://urbantapestries.net/.

Seigworth, Gregory J. (2005), 'From Affection to Soul', in C. J. Stivale (ed.), Gilles Deleuze: Key Concepts, Chesham: Acumen, pp. 159-69.

Seigworth, Gregory J. and Melissa Gregg (2010), 'An Inventory of Shimmers', in M. Gregg and G. J. Seigworth (eds.), The Affect Theory Reader, Durham, NC: Duke University Press, pp. 1-25. 
Thrift, Nigel (2004), 'Intensities of Feeling: Towards a Spatial Politics of Affect', Geografiska Annaler: Series B, Human Geography, 86:1, pp. 57-78.

Tuters, Marc and Kazys Varnelis (2006), 'Beyond Locative Media: Giving Shape to the Internet of Things', Leonardo, 39:4, pp. 357-63.

Wood, Denis (2010), Everything Sings: Maps for a Narrative Atlas, Los Angeles: Siglio.

Zeffiro, Andrea (2012), 'A Location of One's Own: A Genealogy of Locative Media', Convergence: The International Journal of Research into New Media Technologies, 18:3, pp. 249-66. 
1. Massumi's 1995 essay, 'The Autonomy of Affect', is often identified as a foundational text in a Deleuzian/Spinozan strand of affect theory in the humanities. It is reprinted in Massumi, Parables for the Virtual: Movement, Affect, Sensation (2002).

2. Claire Bishop succinctly describes this phenomenon: 'Reducing art to statistical information about target audiences and "performance indicators", the [New Labour] Government prioritizes social effect over considerations of artistic quality' (2006: 180). Sophie Hope has discussed Nold's work in relation to this policy context (2008).

3. In an elaborate diagram hosted on his website, Nold sets out his understanding of related and competing concepts of collective identity in contemporary society, and the different actors involved in mobilising and promoting them. While Nold dismisses stable, place-bound and unconflicted collective identities as a fantasy, what he calls the "cuddly community', he notes the vital role that this fantasy plays in providing the practical conditions under which his own work comes about (available at Nold 2011 ['Concept']).

4. Nold states that the Chartists claimed a figure of six million signatures; the government, after a rapid count, came up with only 1,975,496 signatures, of which many were clearly fictional (2005: 846-8).

5. All the 'Emotion Map' projects are linked to from the Emotion Map website (Nold 2008).

6. Nold has made the data available in KMZ (suitable for Google Earth) and GPX file formats.

7. This example of a performative mapping practice perhaps misses the point that the data interactively manipulated and selectively viewed, as well as the structure of that data, is still a representation rather than a performance; however, Perkins still sees these technologies as producing a performative understanding of maps.

8. See for example the essays collected in Jean Halley and Patricia Ticineto Clough's anthology The Affective Turn: Theorizing the Social (2007) and Melissa Gregg and Gregory J. Seigworth's The Affect Theory Reader (2010).

9. Given the contested nature of affect, it seems fair to cite Massumi verbatim: 'For present purposes, intensity will be equated with affect' (2002: 27). In 'The Autonomy of Affect' at least, he does not trouble that equation. It is significant that Massumi chooses two empirical studies to introduce a largely philosophical treatment of affect, which draws far more substantially on Deleuze, Spinoza and Henri Bergson than it does on cognitive science. Nigel Thrift, writing at a time when the considerable impact of Massumi's article was clear and seemingly with it in mind, notes that, in writing on affect in social and cultural theory in the early 2000s, 'naturalism and scientism are no longer seen as terrible sins' (2004: 59).

10. Clare Hemmings notes that Massumi and another key writer of the affective turn, Eve Kosofsky Sedgwick, both fail to provide any specifics about exactly which parts of post-structuralism and which writers are responsible for the disembodied impasse which they claim has befallen cultural theory. Hemmings argues that this lack of citation or specific engagement is a vital part of their project of positioning affect and ontology (over post-structuralist epistemology) as 'the critical new for the noughts' (2005: 556).

11. Amongst other exhibitions, this phase of the Bio Mapping project travelled with the touring exhibition Day-to-Day Data (Harrison 2005).

12. 'When I was developing this whole thing I kind of started from various kinds of sensors and of course it's easy to get real time data out of it, and to begin with I was playing with real time data, but I made a deliberate choice to do it as this kind of post-reflection': Christian Nold in conversation with the author, 28 July 2010.

13. Relational aesthetics is a term coined by the French curator Nicholas Bourriaud to describe a group of mainly continental European artists that emerged during the 1990s (Bourriaud 2002).

14. A collaboration with designer Daniela Boraschi. 
15. Longitude and latitude are not terms that Spinoza uses. Elsewhere, Deleuze states that he takes them from medieval philosophy: 'In short, if we are Spinozists we will not define a thing by its form, nor by its organs and its functions, nor as a substance or a subject. Borrowing terms from the Middle Ages, or from geography, we will define it by longitude and latitude' (Deleuze 1988: 127).

16. The distinction between tracing and annotative strands of locative media comes from Marc Tuters and Kazys Varnelis (2006). 